MANOUSOS KAMBOURIS

The Association of Historical Studies

KORYVANTES,

Athens, Greece

E-mail: mekambouris@yahoo.com

SPYROS BAKAS

The Association of Historical Studies

KORYVANTES,

Athens, Greece

E-mail: koryvanteshoplites@gmail.com
903/904:355.48

COBISS.SR-ID 254102796

Original research article

Received: January $29^{\text {th }} 2017$

Accepted: October 31 2017

\title{
DUEL AND SINGLE COMBAT: THE HOMERIC RESONANCE OF THE ELITE FIGHTERS - PRACTICE OF THE BRONZE AGE ART OF WAR
}

\begin{abstract}
The Homeric epics are the only descriptive literary source which possess enough detail to interpret material and illustrative evidence into a functional context of war fighting, especially with a view to technique, tactics and, to a lesser extend overall practice. The instrumental role of fighting between two elite, heavily armed warriors is indeed a nice read or story, but this does not exclude functionality and realism; the middle-ages warfare is an exact analogue. Thus if the epic is taken at face value as it was used to be and clearly intended to be, a coherent picture emerges, with armies based on 50-strong basic units, different troop types used in specific mission profiles in tactically competent ways, maneuvering reminiscent of much later eras and both massive and individual approaches for a decisive outcome. The latter, seen both during the campaign of Alexander but also in the Middle Ages is described in great extend and produces an integrated picture of the skills and methods involved, both in set-piece, ritualistic and strictly regulated duels and in more or less random, but unregulated and spontaneous personal encounters leading to single combat within the context of a larger fight.
\end{abstract}

KEYWORDS: DUEL, SINGLE COMBAT, BRONZE AGE, TROJAN WAR, HOMERIC EPIC, ILIAD, TACTICS, ARMY ORGANIZATION, WEAPONRY, PHALANX.

Archeology and tablet deciphering have done much to unravel the material aspect of bronze age world to today's observer. But there is a discernible lack of descriptive evidence, literary or other, to combine with findings and illustrative art of the era into a coherent, functional picture. Especially in warfighting, the commemorative texts of Egyptian pharaonic monuments and similar ones of the fertile crescent provide little information on warfighting. The only vivid and coherent description available is the Hellenic Homeric epics; although we only possess a heavily edited, Athenian-man- dated $6^{\text {th }}$ century BC version with detectable forgery, the main structure provides a large and coherent picture with cases of exemplary detail usually sunned by philologists as "figures of speech" and by historians as "unreliable lore". Still, the massive confrontation which shook and crumbled the bronze age Aegean is described in terms precisely understandable by modern-day military personnel and in detail not seen in literature till the $4^{\text {th }}$ century BC military treatises and historical texts written by war professionals for their kind. 


\section{Armies organization and command}

There is no question that the Trojan and allied army is a feudal conglomerate under the personal command of the Lord of the Hosts of Troy, Prince Hector (who might or might not have been crown prince). The high command, though, rests with the crown council, comprised by the king and a 7-member senate (Hom. Il.III-146) which may veto his plans or impose decisions of strategy (Hom. Il.XV-721/3). After 10 years behind Troy's walls (a timeframe not exaggerated, if compared with the siege of Tyre 598-585 BC by the Babylonians), allied relief contingents have arrived before Prince Hector's offering major battle to the invaders (Othryoneus in Hom. Il. XIII-364, Asteropaios in Hom. Il.XXI-156); they continue to arrive by the day and are thrown piecemeal into battle, as they arrive (XXII-434). The basic administrative unit are the 50 men and the total size of the army is approximately 50.000: 1.000 campfires, with 50 men sleeping, sitting or eating around each one of them (Hom. Il.VIII-558/9).

The Greek army had the same basic unit of 50 , as the main ship is the 50 -oared galley (pentekonter) of unknown model (Hom. Il II-720, XVI170). Nevertheless there are some very large ships carrying 120 troops of a certain contingent (Hom. Il. II-510); whether all of them were doubling as rowers or not is not stated. There were also 20-oared galleys for other missions (I-309). But the similarities of the two armies stop there.

The Greek army is NOT a feudal levy, but an integrated organization with distinct functions and specialist units. During the most part of the Iliad it is indeed operating-and with little success- as a feudal levy as well, since Achilles, the mind and soul of the army and acting Commander-in-Chief/ CiC (as indicated in Hom. Il XXIV-651/8 and directly stated in Hom. Od. III-106) is estranged. Just before the new series of clashes, narrated by Homer in the Iliad, which occur during the 10th year of the war, the elderly tactician Nestor advises the High Commander Agamemnon to deploy the army in feudal manner (Hom. Il II-361/8). This means that for 9 years the army was NOT deployed in such a manner, and this differentiation is obviously due to the absence of Achilles. Once he is back, he clearly issues all the executive directions and orders (Hom. Il XIX-155, XXIV670) and the army is no feudal assembly, but an efficient war machine once more, operating with a plan and efficiency and not simply clashing with the enemy. There are tactical units and respective leaders/commanders (Lochoi, 500-strong in Achilles' own contingent Hom. Il XVI-168/73) although their command is not specified as organic or ad hoc. The decimal system thus implied fits well with the 10-man Oka of the tablets. Many scholars detect dramatic effect and poetic projection in the advice of Nestor, but had it been so the poet would have easily projected it into the past, as he did in other cases, as with the pursuit of Aeneas (Hom. Il XX-187/91).

\section{Tactics}

For army tactics, Achilles favors charge and clash (Hom. Il XX-354/5) and Patroclus, fighting in his stead, does the same (Hom. Il XVI-394/8); this is not always the choice of neither commander (Hector, Agamemnon), who may stop their advance at a distance and exchange missile fire (Hom. Il XV-710), as did the european armies of the 16-18th centuries, while skirmishers, usually the well-protected nobles, may jump in between opposing armies and strike targets of opportunity as exemplified by Antilochos (Hom. Il XIII-559). After a prolonged exchange which has softened up the one opponent, the other one charges (Hom. Il XI-85/90). The reason for avoiding the clash from the first encounter is obviously the lying of the advantage with the offensive weapons; thus rushing to contact with a large and expedient in missile warfare enemy body is ill-advised. Shields and armor are more often penetrated in close quarter combat than not. Menelaus, an important and powerful and wealthy king is hit by 


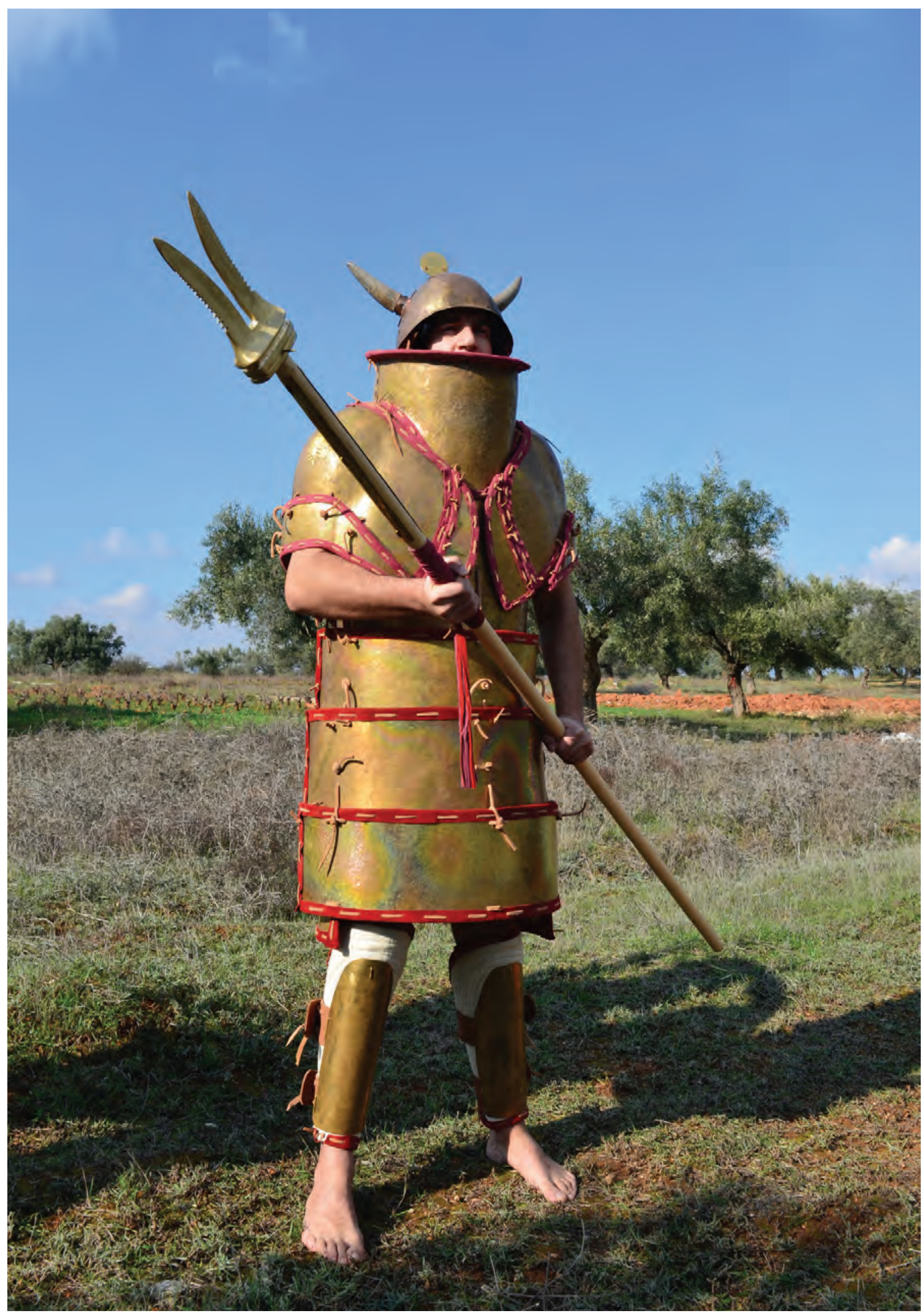

Fig. 1 The arrowpoint (which is explicitly mentioned as “iron” IV-123) pierces through three successive armor parts (IV-133/5); such a succession of armor parts is indicative of Dendra-type panoply and would not have been found in other body parts. Photo credits : Association of Historical Studies KORYVANTES - koryvantes.org 
an arrow and wounded by Pandaros after the arrowpoint (which is explicitly mentioned as "iron" Hom. Il IV-123) pierces through three successive armor parts (Hom. Il IV-133/5); such a succession of armor parts is indicative of Dendra-type panoply and would not have been found in other body parts; the respective armor would have been pierced more easily. But the same warrior's cuirass deflects Helenos' arrow from point-blank (Hom. Il XIII-585/95). Only Achilles (with armor made by a God) suffers no penetration-his greave even staves off a direct spearcast (Hom. Il XXI591/4). But he himself is not very confident on the subject (Hom. Il XX-261/5). Despite this fact, he chooses to strike Hector in a spot not covered by his own, captured armor: as the latter charges leaning forward, Achilles thrusts at the joint of neck and shoulder (Hom. Il XXII-322/6).

Although panoplies are routinely penetrated by missiles, the thing is different with the shields. Archery is not mentioned to pierce shields. Most lethal spearcasts and thrusts are delivered around shield coverage, directly to the body armor or to unprotected body parts. The dramatic description of spearwounds may or may not reflect absence of armor. Such conclusions may be drawn ex silencio only in thorough descriptions. Few hits on armor are repulsed, occasionally resulting in broken spearpoints or even spears-but the latter is considered a god-sent stroke of misfortune (Hom. Il VI306, XIII-564/5) -most probably a failed weapon, or flawed of manufacture. Helmets are routinely giving way under direct hits (thrusts Hom. Il XX398 -and blows Hom. Il XX-475), but are also responsible for some spectacular saves: Hector, Paris and Menelaus are saved by spearcast, swordcut and straight-axe blow respectively (Hom. Il XI350, III-362, XIII-615). Shields, on the other hand are just as often pierced as they repel the points (Ajax's and Achilles' shields are never pierced). Actually, this may imply an imbalance in favor of the shield: piercing it is mentioned as a worthwhile accomplishment and is not a matter of fact. The frequent remark that enemy missiles press hard a hero imply a number of them hitting the mark without piercing it (i.e Hom. Il XV 727). Achilles cast is legendary for piercing everything in its way (Hom. Il XX-99/100), a reputation well-deserved as there is no mention of any parrying of his cast (contrarily to more than a couple of misses) and the very enlightening report that when he missed Asteropaios and the spear was driven deep into earth, his opponent was unable thrice to retrieve it (Hom. Il XXI-170/6). There is direct reporting of efforts to javelin down an opponent behind and not through the shield (Hom. Il XVI-312, XVI609) and Achilles' cast to Aeneas, which brought the latter into a disadvantage, stroke the shield next to the rim, at its thinnest (Hom. Il XX-274/7), begging the question of deliberate aim at that part of the shield versus a miss by the narrowest margin in an effort to target the missile by -or, rather, over-the shield.

\section{Phalanx}

Greeks have the option to revert to very tight phalanx formations (Hom. Il XIII-129/131, XVII352/65); the Trojans cannot reciprocate, nor break them. Of course such formations allow no maneuvering and are used only in last resort and desperate times. It is an open issue whether this difference in formation capability is due to the shields used or to any other factor, such as training, character, morale or drill. Tower shields are not mentioned for Trojans, who do use figure-of- 8 body-shields, as do many Greeks; Hector has a body shield which demands dexterity in moving and handling (Hom. Il VII-238/9) and when thrown back it is felt at heel and neck while running (Hom. Il VI-118); and he is no exception, but the rule. His shield is described also as symmetric (Hom. Il XI-61, VII-250), the greek wording not meaning circular, as usually interpreted, but 8 -figured. Both enemies use round shields of small or moderate size and other, non-circular shapes, especially with the Trojans and their allies. There might also be double-grip shields, as in Pylos 
frescoes, reminiscent of argive shields. The only tower shield directly mentioned is the one of Ajax the Great, who is a most static warrior, never on a chariot or part of any maneuver. Homeric language is inconsistent (such pitfalls ARE indeed expected in poetic synthesis), but it is the only one that might be called "sakos", as the greek term implies something rectangular-ish, which is not compatible with the figure- of- 8 or the elliptical or the round shields.

The Homeric phalanx is a patchwork of intermingled problems and doubts. The way standard shield-bearers, armed with extra-long lances (egxeiae), were deployed is one of such problems. A close phalanx would have them crushed by the leading teams of chariotry. An open deployment would expose them to runners and light infantry. The fresco of Thera, showing a dispersion which allows motion so as to avoid being trampled by the chariot, might imply a relaxed formation which, by means of the length of the lances, allows multiple coverage/ support to a comrade from swarming light infantry.

Body- shield-bearers, armed with extra-long lances (egxeiae) were most probably NOT deployed in tight phalanx. First, being able to get INTO the shield is important when NOT in phalanx. In phalanx, enough to go behind the shield, as hoplites would show some centuries later. A close phalanx would have been crushed by the leading teams of chariotry, especially if supported by powerful and accurate missile fire. An open deployment, however, would expose them to runners and light infantry. The fresco of Thera, showing a dispersion which allows motion so as to avoid being trampled by the chariot, while by the length of the lances remaining able to support a comrade from light infantry swarm, is perhaps a more viable paradigm. The dispersed troopers do not offer a solid target for massive archery but must be picked one by one, which is tricky if they are not in even spaces and straight lines and files. The spears offer crossfires, and evasion of charging chariots while lancing at the team or the crew is possible. The concept is still viable if lance is substituted for spear, and archers can be swarming within the formation. The shorter spear might turn the formation a bit denser, but not too much; this might be the Homeric paradigm for both opponents.

The greek dense phalanx is clearly depending on three things (Hom. Il XIV-371/82): men (must be heavy and strong, not light and agile), shields and spears. Longer spears are better suited for porcupine formations and it is very probable that explicit reference to spearfighters in both armies implies use of long spears- rather lances "egxea"instead of the more typical "dory" double-use spear which was the current standard and seen in Pylos' fresco arming light infantry. For the Greeks the best case-study is the contingent of Avantes, while a Thracian contingent is the respective from the Trojan side (Hom. Il IV-533). It is explicitly mentioned for Avantes that their spears break through cuirasses (II-543/5) and armor; thus they are special weapons compared to standard "dorata”. But the heart of the issue lies with the shields: Homer mentions partial redistribution of weaponry (unevenly issued as a result of conscription practices, a millennia-old problem) to have the heavy shields in front, to shield a phalanx (Hom. Il XIV-376/7). This is not necessarily correct: the lighter shields, termed «laiseia» (Hom. Il V-453) and being either the Warrior Vase reverse crescent copper-faced models, or circular ones, either one-handled (as the Herzsprung example) or two-handled, as in Pylos frescoes, allow denser packaging; and denser packaging of men means a more threatening and repulsive wall of spearheads (as shown by the Macedonian phalanx, which, according to Diodoros, just brought back to life the Homeric phalanx), which clearly intercepted Hector and the Trojan onslaught (Hom. Il XIII-145).

The last issue on greek tactics is the "tower" (Hom. Il IV-334), an effective offensive but not defensive formation. It must have been similar to 19th century columns used by the Napoleonic French infantry for prompt assault minimizing 
exposure to line fire and giving momentum in the collision. The rationale should have been similar in the bronze age and a kind of drill would have allowed transformation of infantry units. It is possible that this kind of formation was in the heart of classical assault formations as the deep phalanxes of Thebans in Delion (424 BC/ Thuc. IV, 93); Nemea (394 BC/, Xen. Hell. IV, II, 14); Leuctra (371 BC/ Xen. Hell. VI, IV, 11 ); and second Mantinea (362 BC/ Xen. Hell. VII, V, 13).

\section{Personal skill and duel practices}

The elite, heroic warriors combine heavy armor with mobility; both Achilles and Hector are fleet of foot, excellent charioteers, big of stature and very strong, epitomizing the heroic concept of "tall, strong and brave" while adding the "fast". The succession of offensive and defensive postures, techniques and choices in duels (both formal and informal-especially in the latter) is intriguing. Combined with the characteristics of the prominent fighters (big stature, heavy, high-tech armor and fleetness of foot), the issue is highly reminiscent of current protocols for air battles by fighter pilots, who engage the enemy successively using the longer-range weapons to gain time and advantage as they close in for shots with shorter range ones. In the Homeric duel, both antagonists start with a spear and range is essential. Thus a spearcast, especially a sudden or stealthy one might finish the issue immediately and effectively. If the shot missed, though, the warrior is at a disadvantage. A cast spear, if perceived, can be evaded or parried and the enemy may retaliate. As the first offender is spearless, the retaliatory strike may not be another, waited-for cast, which entails a very high probability of being evaded or parried as it is expected; a spearthrust is much more probable. The thrust permits better aiming, applies more strength so as to pierce shield and armor or even helmet (Hom. Il XX-395), does not spend the weapon allowing an immediate repeat of the assault and it may allow secondary, cut/ slash follow-ups if the thrust is dodged. Practically a swift close-up for a spearthrust is the best offensive option if the adversary is spearless, keeping the offender way out of secondary weapons' range. Achilles does so twice with Hector (Hom. Il XX-440/6) and Hector himself prefers thrusting at Patroclus, not casting (Hom. Il XVI-820). The reason the thrust is superseded by spearcasts in terms of frequency is the inherent surprise/stealth of the latter- not to mention the distance advantage: The cast, naturally, outranges the thrust by far, thus many warriors missing their mark with a shot, easily resort to flight rather than sustain an enemy retaliation, with much better possibilities to make good their escape than if engaged in closer range.

The truth, though, is that once a spear is cast, the targeted warrior, if able to perceive it (not a very usual thing) must take some action. At the time he spends to evade (Paris in Hom. Il. III-360) or parry (Achilles in Hom. Il XX-261/3), the offender, if fleet and fast, has the opportunity to close the distance and position himself favorably for a second shot. This is either with the secondary weapon, delivering a blow from point-blank, or with a second, reserve spear -which is rarely, if ever, cast. Thus, an early spearcast even if missing its mark, may be advantageous: if hitting the shield, it may weight it down (Hom. Il XX-276/83). If parried or evaded, it has pushed the target into the defensive allowing the offender a better footing while reverting to the secondary weapon from close range, perhaps within the minimum range of the enemy's primary weapon. In Hom. Il XX259/290 Aeneas had the first cast and Achilles, after parrying it, reciprocated and followed suit with the sword. Aeneas, despite having the first shot, reverts to stone, which means he is not in position to draw sword and receive the attack: Achilles' cast kept him busy long enough for his adversary to acquire a definite advantage. Thus, when casting a spear, the heroes chased after their cast using the force of the cast proper to follow the missile- and not to recoil as today's athletes. 
A secondary reason for this follow-up might be to retrieve the weapon (Hom. Il III-529); though, the main reason is to press the attack home with the sword, as does Menelaus against Paris (Hom. Il III-361/62), and Achilles against Aeneas (Hom. Il XX-283/5) before the initiative is seized by the opponent. In Hom. Il XIII-512 Idomeneus is described as of age so as not to be able to follow up.

It might have been a Trojan tactic to aim for the legs when facing heavy opponents. The proverbial “Achilles' heel” is not an isolated incidence. In Hom. Il XI-379 Paris' arrow nails Diomedes' foot to the ground by hitting the ankle. It might be more of skill and intention and less of luck to hit two prominent heroes at the same spot, heroes with highly regarded armor, one of them having previously survived a direct hit of an irontipped arrow at the cuirass (Diomedes, striken by Pandaros in Hom. Il V-99). Last, Agenor shot his spear at Achilles' shin (Hom. Il XXI-591), which is the same concept-or possibly a slight miss, if he aimed for the ankle and foot and missed his precise mark as Achilles charged forward, taking thus the shot on the brand-new, god-forged greave which sustained it admirably.

\section{The weapons}

The warrior is always equipped with a general purpose spear, for casting and thrusting alike, and generally carried in pairs (Hom. Il VI-104, XIII559). This reminds us of the very later Persian "palta" of the cavalry, much praised by Xenophon (Xen. Hell. III-4.14 and Eq XII-12). The pair of spears is mentioned many a time Hector jumps out of his chariot, and this might imply that he changes weapons, from long chariot lance to pair of spears. It is obvious that both lance and spears are routinely secured within the chariot. An excellent example is Patroclos who sets out with two spears in Hom. Il XVI-139 but after casting one to Sarpedon's mate and never recovering it he is explicitly mentioned as fighting hence with one (Hom. Il XVI-733, XVI801), which he does not cast and for missile he re- verts to stones while having the spear at his left hand. In another very enlightening excerpt (Hom. Il XIII-559), Antilochos, son of Nestor (a master charioteer in Hom. Il XXIII-306/8), is mentioned as fast, agile and always eager to fight, either casting from afar, or charging at contact to thrust with his spear. In both cases the spear is the main weapon, which vividly illustrates the merit of the tworole "dory" which can be thrown or thrust and is carried in pairs.

The use of secondary weapons is important, after the spear is cast or broken: there is one mention of the straight axe, in Trojan ally's use (Hom. Il XIII-612 $\alpha \xi \xi i v \eta$ instead of " $\pi \dot{\varepsilon} \lambda \varepsilon \kappa v \varsigma$ "। regular axe for tree falling in Hom. Il XXIII-115) and then a direct mention of both straight and conventional axes in Hom. Il XV-710. The usual choice is the sword. Homeric terminology is inconsistent, but one can discern the very long, thrusting weapon ("fasganon" in Homer pakana in the tablets) and the sturdy, double use "aor", which chops off limbs and heads (Hom. Il XX481). A distinguished such weapon is mentioned as being of Thracian origin, imported to Troy for prince Helenos. In Homer, though, swords often break. Though, during the middle ages the main kind of straight sword (the broadsword) was triangular and long; despite this fact it was excellent cutting weapon, and it might well have been the same with fasganon: apart from the obvious, to kill someone thrusting through a body shield-perhaps the raison-d' etre for copper-covered bodyshields in Iliad, which are not mentioned in Odyssey- the long, smart, thin weapon might have been excellent in finding an opening in body armor plate interface to pierce (as did the rapier in Europe) or to precisely slash- a good reason for neckguards in the Dendra panoply. On the other hand, the role of aor is straightforward: to defeat, not circumvent, armor. Thrusting (Hom. Il XXI179) or chopping/cutting, it is a weapon of force combined with good technique. Its use allows breaking helmets and splitting the heads (Hom. Il XX-475), decapitating (Hom. Il XX-481) or 


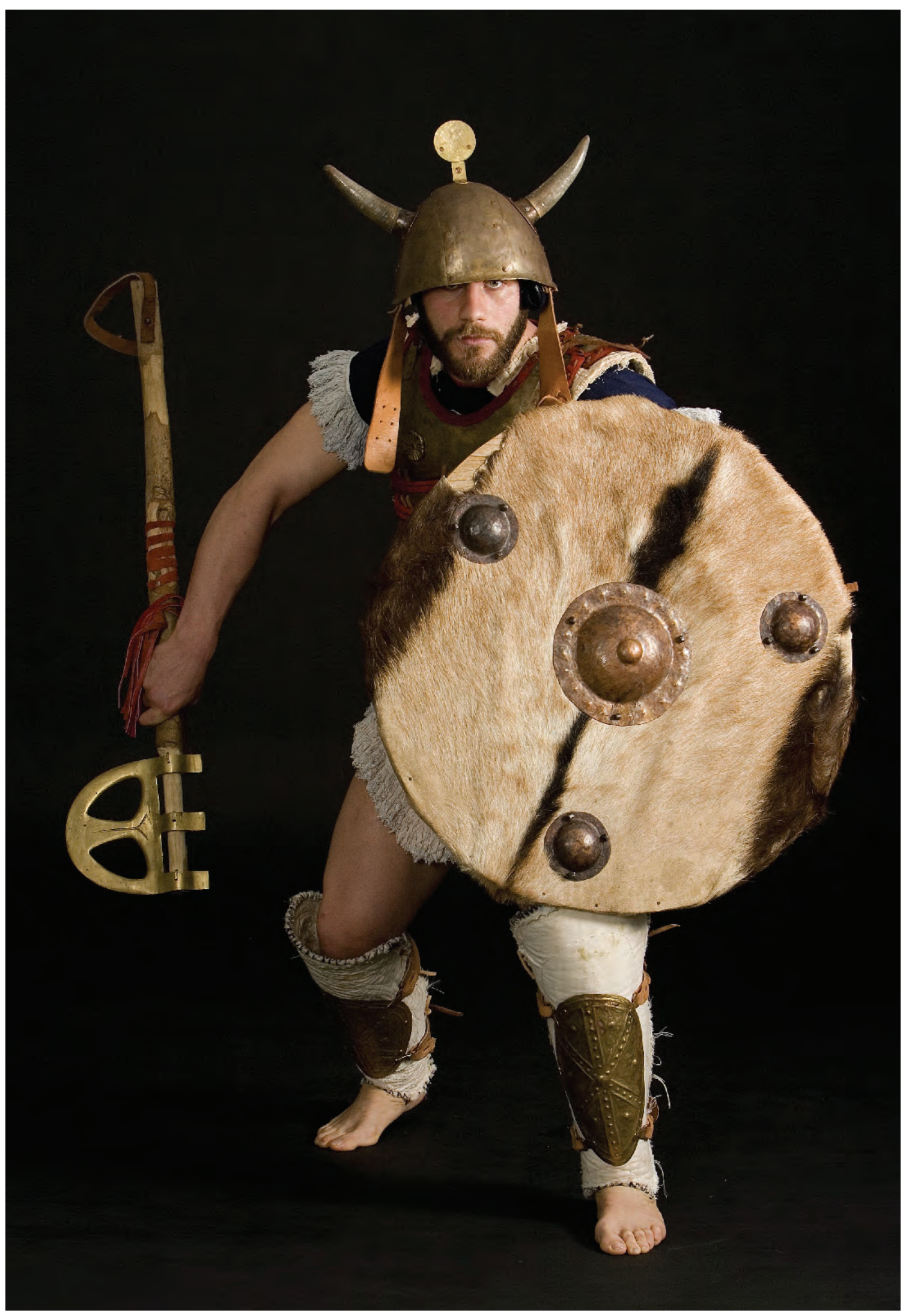

Fig. 2 Reverting to secondary weapon as missiles are spent.

Photo credits : Association of Historical Studies KORYVANTES - koryvantes.org 
maiming by cutting through armor plate. Straight or bulged near the point ("oarlike”, Hom. Il XV$713, \mathrm{XX}-475)$, iron or copper/bronze, the aor is the weapon of the stronger, not the most versatile warrior, and it is parried only by a shield, preferably a bodyshield-which is perhaps the reason fasganon did not go straight out of favor once aor had been introduced.

It is a little appreciated fact that swordplay, as form and technique, is directly affected by other field parameters, the most prominent being the missile factor: battlefields where missile fire is abundant (not only arrows, but javelins and slingstones as well) deny the opportunity for advanced, picturesque swordplay as interpreted for the middle ages. The well-trained swordfighter has to combine his blade with a shield and merit lies to swift, accurate and powerful blows while offering the least opening when moving his shield-not just to the immediate opponent, but to a hidden archer as well.

To surmise the above, if two heroes close at each other in the open, for an informal duel (not formal single combat) each must decide if throwing a spear, to finish the engagement early on, is the best option, or charging head-on for a spearthrust is best. The cast is minimal danger, but in open confrontation, especially on the run, misses are often. If the weapon misses indeed, the opponent may return the cast at leisure, but this entails a high probability of missing as well; on the contrary, the only antagonist with a spear at hand has a very nice opportunity to approach at ease with the spear as a thrusting weapon (Hom. Il XIII-605) and attempt any number of thrusts with virtual impunity, as any spear outranges any hand weapon (sword, mace, axe). The equalizer is the fact that once a spear or javelin is incoming, the target must take evasive or parrying action, thus offering a minor but crucial window of opportunity in terms of time, posture and geometry to the offender for drawing his sidearm of choice and pressing the assault home. This might lead either to delaying the cast till the last moment, which produces a quickdraw situation, eventually termi- nating with both opponents hit by simultaneous spearcasts (Hom. Il V-655/60) or both opponents exchanging spearthrusting (Hom. Il XV-528/536); it may also lead to both opponents reverting to their sidearms in time (Hom. Il XIII-610/615). As the sidearm is a substitute for the spear, the same rules apply: both antagonists go for the first blow, with cases of strokes from both opponents been delivered simultaneously (Hom. Il XIII-610/615); else, a succession of blows ensues (Hom. Il XVI335/340).

\section{BIBLIOGRAPHY}

\section{Ancient Sources}

Herodotus Mousai

Homer The Iliad

Homer The Odyssey

Sun Tzu The Art of War

Thucydides Historia

Xenophon On horsemanship

Xenophon Hellenica

\section{Contemporary Scholarship}

\section{Arnold, J. R. 1982}

A Reappraisal of Column Versus Line in the Napoleonic Wars, Journal of the Society for Army Historical Research LX no. 244.

\section{Bossert, H. T. 1946}

Asia, Literarische Fakultat der Universitat Istanbul no. 323, Forschungsinstitut fur altvorderasiatische Kulturen no. 2. Istanbul.

\section{Castleden, R. 2005}

The Mycenaeans, Routledge.

\section{Chadwick, J. 1976}

The mycenean world, Cambridge University Press.

Doumas, C. 1992

The Wall-Paintings of Thera, Thera Foundation. 
Lejeune, M. 1968

La civilization mycenienne et la guerre, in Vernant J-P ed., Problemes de la guerre en Grece an-

cienne, Paris: Ecole des Hautes Etudes Anciennes Sociales.

Liddell, H.G. and Scott, R. 1889

An Intermediate Greek-English Lexicon, Clarendon press.

Shaw, R. L. 1985

Fighter Combat, Naval Institute Press.

Ventris, M. and Chadwick J. 2015

Documents in Mycenaean Greek, Cambridge University Press.

Youngblood, R.F., Bruce, F. F., and Harrison, R. K. 2012

Unlock the Bible: Keys to Exploring the Culture and Times.

https://linearbknossosmycenae.wordpress. com/2013/08/21/a-linear-b-tablet-listing-8640swords/

\section{REZIME \\ DVOBOJ I POJEDINAČNA BORBA: \\ HOMERSKI EHO O VEŠTINI \\ ELITNIH BORACA U UMETNOSTI \\ - NAČIN RATOVANJA U \\ BRONZANOM DOBU}

KLJUČNE REČI: DVOBOJ, POJEDINAČNA BORBA, BRONZANO DOBA, TROJANSKI RAT, HOMEROVI EPOVI, ILIJADA, TAKTIKA, VOJNA ORGANIZACIJA, ORUŽJE, FALANGA.

Homerovi epovi su jedini književni izvor sa dovoljno detaljnih opisa za tumačenje materijalnih i ilustrativnih dokaza i njihovo stavljanje u funkcionalni kontekst ratnog sukoba, naročito $\mathrm{u}$ pogledu tehnike, taktike, a u manjoj meri i celokupne veštine. Opis borbe između dva elitna, teško naoružana ratnika je zaista dobro štivo ili priča, ali to ne isključuje funkcionalnost i realizam; srednjovekovno ratovanje pruža preciznu analogiju. Dakle, ukoliko ep prihvatimo kao činjenicu, kao što je i prihvatan i kao što mu je i bio cilj, pojavljuje se koherentna slika, sa vojskom koja se sastoji od 50 jakih osnovnih jedinica, različitih vrsta trupa koje se koriste za specifične vrste misija na taktički kompetentne načine, a čiji manevri podsećaju na mnogo kasnije periode, sa oba pristupa i masovnim i individualnim, kako bi došlo do odlučujućujućeg ishoda. Ovaj poslednji, koji se vidi i tokom Aleksandrovih ratnih pohoda, ali i u srednjem veku, naširoko je opisan i daje objedinjenu sliku o primenjenim veštinama i metodama, kako u elaboriranim, ritualnim i strogo regulisanim dvobojima, tako i u manje ili više nasumičnim, ali neregulisanim i spontanim ličnim susretima koji dovode do pojedinačnih borbi u kontekstu veće borbe. 